serious trouble. On the other hand, a case is reported in a recent number of the Guzette médicale de Paris, by M. Rosin, where an injeetion into the vagiua and uterus of a two per cent. solution caused vomiting, subnormal temperature, and death in collapse. The quantity of the liquid injected into the uterus in three days was from seven to eight quarts. This eontained about four and one-half ounces of creolin.

As a disinfectant, creolin is efficient; according to Esmarch, a one per cent. solution rids one almost immediately of all bad odors, except its own, whieh is not agreeable, though better than that of carbolic acid.

In enulsions containing two and a half to five per cent., it is a powerful germicide.

It lias heen found serviceable especially in diseases of the nose, ears, and throat; Schnitzler recomınends it in all affeetions of the buecal cavity caused by microürganisms; he has found it very useful in tubercular laryngitis.

As regards the internal adininistration of this drug, it is important to bear in mincl the dangers of bringing a substance so irrituting as creolin in contact with the stomnach and iutestines. -Gr.tectle médicale de Puris, December 22, 1888.

Experiment3 made in the bateriologieal laboratory at Königsburg, by $\mathrm{DR}_{\mathrm{R}}$. WASHBOURN, appear to prove that crcolin, though far less toxic than carbolie neid, yet possesses more distiuctly poisonous properties than has been supposed.

Professor Badmgarter also finds that ereolin is a strong poison for the animal organism, but the poisonous dose is relativcly large, so that the value of ereolin as a loeal antiseptic and disinfectant is not prejudiced by his experiments, which only show that its internal administration must not be pushed too far.

The amount which would have to be absorbed from a wound would be so large that practieally there would not seem to be any danger attending its use in dressings.

Experinents by BeHrisg lead him to the ennclusion that as an antiseptie it is three or four times weaker than earbolic acid, and that it cannot be relied upon as a disiufeetant.-British Medical Journal, February 2, 1889.

\title{
Nitrite of Ethyl and Spirit of Nitre.
}

DR. LEECH has contributed an interesting article on the comparative effects of spiritus ætheris nitrosi and solution of nitrite of ethyl.

Pharmacological considerations certainly render the practical identity of the two solutions very probable, Aldehyde, alcoliol, and nitrite of ethyl are the principal substances present in sweet spirit of nitre. Paraldehyde is not present in sufficient quantity to exert any perceptible physiological effects. Spirit of nitre has long beell a popular renedy for eausing an increase in the urine and perspiration. As a diaplooretic, the solution of ethyl is as efficient as the spirit of nitre. The diuretic effect of both preparations does not appeur to be high. In cases of difficulty of breathing, due to constriction of the bronchial tubes, and in cases of contraction of the muscular arterioles, the spirit and the solution were found to be of great and equal value; they 
tend to prevent the onset of the original attack, and by dilating the arterioles, they reliere an overloaded heart.-Lancet, February 2, 1889.

\section{SACCHARIN.}

After the constant use of saccharin for over a year, DR. H. MACNAdaBton JoNes has never known any injurious effects to follow its exhibition, though several of his patients have substituted it for sugar altogether in their food.

The great mistake generally made with all preparations of saccharin is that the intensely sweetening property of saccharin is overlooked and too much is used, both for purposes of diet-as when it is added to tea or coffee-and when it is prescribed in mixtures, powders, etc.

It $h$ as been found useful in disguising the taste of quinine, muriated tincture of iron, antipyrin, salicylate of soda, salicin, the oils of copaiba and santal (either of these oils emulsified by the compound powder of almonds in which the acacia has been incrcased by twenty-fire per cent. and the sugar replaced by an equivalent of saccharin, forms a mixture that is comparatively palatable, and owing to the antiseptic property of the saccharin it keeps much longer than one made in the other way); its utility in einulsions as a preservative is very great, and it is noteworthy in the case of cod-liver oil, guaiacum, hydrastis, cascara sagrada, and chloride of ammonium.

A palatable biscuit for diabetics may be made from gluten flour, 11.5; butter, 2.75 ; eggs, 8.5 ; saccharin, 0.01625 in each biscuit.-Lancet, February 2,1889 .

Prof. Attrield, one of the editors of the last edition of the British Pharmacopceia, has been estimating tbe place of ascharin in pharmacy, and he has published some thirty galenical formulw in which saccharin replaces sugar, either without altering the strength of the preparation in ally way, or else so modifying it that the saccharinated compound may be termed "concentrated." In the former case the place of syrup is taken by powdered tragacanth, or, in special instances, by gluten.

Prof, Attfield regards the advantages of saccharin as fourfold. It enables many medicinal confcctions, powders, and lozenges to be given in comparatively small bulk. It is able, by the intensity of its sweetness, to mask the nauseous taste of many drugs; it is not liable to ferment, and hence will yield permanent preparations in placc of those made with sugar, which would frequeutly spoil, especially if submitted to high temperatures in transport. Lastly, the advantage of " sweet," but not "harmfully sweet," is once more urged. The slight solubility of saccharin has been so often remarked upon that good service is rendered by the description of a form of "soluble saccharin," and by the formula for a simple solution of saccharin of the same degree of sweetness as the syrups of the British Pharmacopoia. The nomenclature adopted for the various formulæ is admittedly open to serious objection, owing to the confusion likely to arise between saccharium and saccharine.Lancet, January, 1889.

\section{Myrtol as a Disinfectant.}

Prof. Eicheorst is of opinion that myrtol will leave all other disinfectants in the background in safety and quickness of action. Myrtol is repre- 